Winter 2003

\title{
Exercising Public Authority Beyond the State: Transnational Democracy and/or Alternative Legitimation Strategies
}

Jost Delbruck

Indiana University School of Law

Follow this and additional works at: https://www.repository.law.indiana.edu/ijgls

Part of the International Law Commons

\section{Recommended Citation}

Delbruck, Jost (2003) "Exercising Public Authority Beyond the State: Transnational Democracy and/or Alternative Legitimation Strategies," Indiana Journal of Global Legal Studies: Vol. 10 : Iss. 1 , Article 3. Available at: https://www.repository.law.indiana.edu/ijgls/vol10/iss1/3

This Symposium is brought to you for free and open access by the Law School Journals at Digital Repository @ Maurer Law. It has been accepted for inclusion in Indiana Journal of Global Legal Studies by an authorized editor of Digital Repository @ Maurer Law. For more information, please contact rvaughan@indiana.edu.

\section{$\Psi$}

JEROME HALL LAW LIBRARY

INDIANA UNIVERSITY

Maurer School of Law
Bloomineton 


\title{
Exercising Public Authority Beyond the State: Transnational Democracy and/or Alternative Legitimation Strategies?
}

\author{
JOST DELBRÜCK
}

INTRODUCTION

The question of the legitimacy of exercising public authority, or more precisely, the legitimacy of governance or government, has been discussed since ancient times. There is a formidable host of literature on the topic, written by philosophers, political scientists, sociologists, and-last but not least-legal scholars. Not surprisingly, the debate over the meaning and the theoretical foundation of the concept of legitimacy has been, and still is, quite controversial. ' Furthermore, the meaning of legitimacy in the exercise of public authority and its foundation has changed with changing social and political conditions over time. ${ }^{2}$ To mention but a few important changes: legitimacy of the rule of kings and princes in the medieval feudal order had a different meaning from the legitimacy of kings or princes after the emergence of the modern territorial state; and even greater changes occurred in the post-French Revolution era and the late nineteenth century under the impact of legal positivism, when metajuridical foundations of the legitimacy of public authority became no longer acceptable. ${ }^{3}$ In our time, dealing with the problem of the legitimacy of public authority has become additionally complicated because under the impact of globalization-understood as a process of denationalization-public authority is no longer exclusively exercised within clearly defined territorial entities, i.e. within the sovereign states. Rather, the "production of public goods" or the performance of hitherto genuinely state

\footnotetext{
* Professor Emeritus of Law, Christian-Albrechts-Universität, Kiel, Germany; Professor of Law, Indiana University School of Law, Bloomington; Faculty Editor, INDIANA JoURNAL OF GLOBAL. LEGAL STUDIES.

1. For a comprehensive account of the divergent approaches to conceptualizing legitimacy, see Thomas Würtenberger, Legitimität, Legalität, in 3 GESCHICHTLICHE GRUNDBEGRIFFE: HISTORISCHES LEXIKON ZUR POLITISCH-SOZIALEN SPRACHE IN DEUTSCHLAND [BASIC CONCEPTS IN HISTORY: HISTORICAL DICTIONARY ON THE POLITICAL-SOCIAL LANGUAGE IN GERMANY] 677-740 (Otto Brunner et al. eds., 1982).

2. Id. at $677-78$.

3. The rejection of metajuridical legitimation of public authority in the writings of legal scholars as well as political scientists in Europe applied in constitutional monarchies and republican, democratic states alike. See ANNE PETERS, EleMENTE EINER THEORIE DER VERFASSUNG EUROPAS [ElEMENTS OF A THEORY OF THE EUROPEAN CONSTITUTION] 506-15 (2001).
} 
tasks, like external security and economic and social welfare, has been shifted, in part, to international and sometimes supranational non-state entities that are constituted by states, but have their own legal status and capacity to act alongside the states. ${ }^{4}$ In other words, we are facing a multilayered system of governance ${ }^{5}$ in which public functions are performed by states (including internationally active substate units like member states of a federal state, or even local communities ${ }^{6}$ ) and by international and supranational organizations, supplemented by the increasingly important activities of non-governmental organizations that participate in international decision- and law-making and in the enforcement of international law. ${ }^{7}$ The challenge posed by these developments with regard to the legitimacy of the exercise of public authority is all the greater because we cannot simply transfer the traditional strategies of legitimizing public authority to the transnational entities that wield public authority within the multilayered system of governance. A simple transfer is impossible because the traditional concepts of legitimacy, particularly those developed since the establishment of the Westphalian state system, are almost inherently state-centered. The result is that in the present debate over the

4. From an international legal perspective the position that international governmental organizations possess legal status and the capacity to act under international law is undisputed today. In international relations theory, however, adherents to the realist or neo-realist school reject that view by maintaining that these organizations are nothing but instruments in the hands of the powerful nations to pursue their national power interests. See WERNER LINK, DIE NEUORDNUNG DER WELTPOLITIK: GRUNDPROBLEME GLOBALER POLITIK AN DER SCHWELLE ZUM 21. JAHRHUNDERT [THE NEW WORLD ORDER: BASIC PROBLEMS OF Global Politics at the Threshold of THE 21ST CENTURY] 108, 114 (1998). See also HaNS J. MORgenthaU, POLITICS AMONG NATIONS: THE STRUGGLE FOR POWER AND PEACE (1960) (the founder of the "realist school"); Hans J. Morganthau, Political Limitations of the United Nations, in LAW AND POLITICS IN THE WORLD COMMUNITY, 143, 150 (George A. Lipsky ed., 1953)("There is no such thing as the policy of an organization, international or domestic, apart from the policy of its most influential member or members.") For a critique of the realist stance, see KLAUS DICKE, EFFIZIENZ UND EFFEKTIVITÄT INTERNATIONALER ORGANISATIONEN: DARSTELLUNG UND KRITISCHE ANALYSE EINES TOPOS IM REFORMPROZEB DER VEREINTEN NATIONEN [EFFICIENCY AND EFFECTIVENESS: ELABORATION AND CRITIQUE OF A TOPOS WITHIN THE REFORM PROCESS OF THE UNITED NATIONS] 340-45 (1994); Volker Rittberger, Theory of International Organizations, in 2 UNITED NATIONS: LAW, POLICIES AND PRACTICE 760, 763 (Rüdiger Wolfrum ed., 1995).

5. DAVId Held, Democracy AND the Global ORDER, 234-35 (1995) (speaking of a transnational, common structure of political action, "a global and divided authority system-a system of diverse and overlapping power centres, shaped and delimited by democratic law."); see also PETERS, supra note 3, at 187 89 (regarding the EU/EC as a multilevel system).

6. See Alfred C. Aman Jr., The Globalizing State: A Future-Oriented Perspective on the Public/Private Distinction, Federalism, and Democracy, 31 VAND. J. TRANSNAT'L L. 769, 837-70 (1998).

7. See Abram Chayes \& ANTONIA HANDler Chayes, THE NEW SOVEREIGNTY 23-24, 184 (1995); SONJA RIEDINGER, DIE ROLLE NICHTSTAATliCHER ORGANISATIONEN BEI DER ENTWICKLUNG UND DURCHSETZUNG INTERNATIONALEN UMWELTRECHTS [THE ROLE OF NON-GOVERNMENTAL ORGANIZATIONS IN THE DEVELOPMENT AND IMPLEMENTATION OF INTERNATIONAL ENVIRONMENTAL LAW] 218-78 (2001). 
"democratic deficit" of the European Union/European Community (EU/EC), there are vociferous critics who simply deny the possibility of a genuinely democratic legitimation of this supranational public authority. The critics argue that the EU/EC lacks a homogeneous nation, on the one hand, and statehood, on the other hand. In short, this position denies the possibility of transnational democracy a limine. To reject this position as dogmatist does not mean to deny that there are indeed serious theoretical, but also mostly practical, problems to be solved in order to realize transnational democracy. We shall come to that shortly. ${ }^{8}$

The fact that, in the search for strategies to strengthen the legitimacy of the exercise of public authority, beyond the state, democratization of the inter- and supranational institutions has so far received the most attention must not make us lose sight of the fact that there are other approaches to legitimizing acts of public authorities. Some of these are related to the concept of democracy or, depending on how democracy is defined, ${ }^{9}$ are an essential part of democracy, like transparency and accountability. Others are independent of democracy, but nevertheless relevant means to establish legitimacy. Thus, the paper will proceed as follows. Part I provides a concise overview of the development of the concept of legitimacy and its present understanding. Part II will deal first with the issue of transnational democracy as a means to legitimize the exercise of public authority beyond the state, and then with alternative strategies or approaches to the legitimation of transnational public authority. A concluding section will argue that both transnational democracy (or at least elements of it) and alternative approaches are necessary gradualist and reformist ways of coping with the problem of legitimizing the increasingly important and effective exercise of public authority beyond the state.

\section{THE DEVELOPMENT AND MEANING OF THE CONCEPT OF LEGITIMACY}

Within the framework of the present paper, it is neither possible nor necessary to deal extensively with the late Roman and medieval concepts of "legitimus" from which the concept of legitimacy is derived. The adjective legitimus was used to denote the legitimate ruler, who is invested according to the law of the land and thereby according to the will of God, in contrast to the

8. Infra Part II.B.

9. See PETERS, supra note 3, at 630-51 (for a concise review of the different concepts of democracy); see also infra Part II.C. 
tyrant. ${ }^{10}$ It is also worth mentioning that medieval thought did not recognize a distinction between "legality" and "legitimacy," terms that did not emerge until the early modern times. ${ }^{11}$ At that time, the term legitimus was used in two ways. Public authority was considered legitimate as part of the moral order which ultimately rests on God's will. Alternatively, public authority was accepted as legitimate if the ruler was brought into office by election or according to the hereditary order, and the exercise of public authority was bound by positive law, resting on the consensus of the people or pursued for the public good. ${ }^{12}$ In the era of absolutist monarchy, particularly in France, legitimacy was combined with the concept of sovereignty, so that legitimacy was defined as "l'autorité Souveraine, pour se faire obéir par les peuples qui lui sont sousmis" and as an authority "qu'elle se doit proposer pour sa fin principale, de procurer par toutes sortes de moyens le bien de ses sujéts."13 Sovereignty thus is made a constitutive element of legitimacy and thereby the state-centeredness of legitimacy was further strengthened. During the era of Enlightenment, legitimacy became more and more secularized. The new understanding of legitimacy viewed its foundation as the free consent of society. Thus, legitimacy became closely linked with the emerging idea of democracy and the sovereignty of the people or nation. The political philosophies of Locke, Rousseau and Kant base the legitimacy of government on the social compact/contrat social. ${ }^{14}$ However, the era of Restoration after the end of the Napoleonic Wars brought a renaissance of the religiously-oriented legitimacy of the monarchs whose authority, according to Talleyrand, Metternich, ${ }^{15}$ and many - particularly German - political philosophers and legal scholars, rested ultimately on the will of God. ${ }^{16}$ The rivalry of the democractic and the theocratic foundation of legitimacy became the leading issue in

10. Würtenberger, supra note 1 , at $680-88$

11. Id. at 681-84.

12. Id at $684-88$ (pointing out that the latter approach was favored by rational natural law, i.e. by Althusius, who emphasized the consent of the people and the pursuit of the bonum commune as legitimizing elements); see also PETERS, supra note 3, at 505 (emphasizing the emerging need to provide for an explicit justification of positive law enacted by the ruler. Justifications were argued on religious or secular bases).

13. CARDIN LE BRET, DE LA SOUVERANETÉ DU ROI 1 (1635); see also Würtenberger, supra note 1, at 690 (for further references).

14. See John Locke, Two Treatises on Government 230-31 (Peter Laslett ed., Cambridge Univ. Press 1988) (1690); JEAN JACQUES ROUSSEAU, DU CONTRAT SOCIAL, (Union Générale D’Éditions, 1963) (1762); IMMANUEL KANT, METAPHYSIK DER SITTEN. DAS OFFENTLICHE RECHT, $\S 43-49$ (Wilhelm Weischedel ed., 1968) (1748).

15. See Würtenberger, supra note 1 , at $697-701$

16. Id. at 701-06. 
nineteenth-century Europe. The battle cries were "sovereignty rests with the people" on the one side, and "restoration of the principle of legitimacy of the king" on the other. Talleyrand and Metternich elevated dynastic legitimacy to the level of the leading paradigm of the Restoration era, distinguishing between the traditional legitimate dynasties and the illegitimate revolutionary governments. ${ }^{17}$

In the twentieth century and up to the present, the concept of legitimacy lost its religious basis completely, and the understandings of legitimacy became more diversified than ever before. It is impossible to follow all the schools of thought and approaches to establishing the foundations of legitimate government in the present context. Suffice it to say that legitimation of government by the consent of the people (the democratic school) is the dominant stance, but that positivist concepts of legitimacy are also voiced in several variations: The legitimacy of governments cannot be derived from external (metajuridical) sources, but is to be founded on the legal order itself (the state as a self-referential system). Legitimacy is produced within the state by orderly process (legitimation by procedure or by free discourse). ${ }^{18}$ Max Weber forwarded the idea that legitimacy of governments rests on empirically verifiable acceptance. These are but a few examples of the diverse modern concepts of legitimacy. With regard to Weber, it must be emphasized that the empirical acceptance of a government by the people is not necessarily linked to the democratic process. ${ }^{19}$ As an empirically verifiable fact, acceptance is most likely to be an ex post consent, although in a democratic system it may also be an ex ante consent, as in periodic elections, which express both ex post acceptance and also ex ante consent. ${ }^{20}$ A third position argues that even democratic process alone does not necessarily provide for legitimacy. It also has to rely on external value foundations, ethical standards expressed in the constitution that are to guide the political process. ${ }^{21}$

17. PETERS, supra note 3 , at 505.

18. See id. at 505-17 (for a concise overview and critical analysis of the positivist schools of thought). See also Hasso Hofmann, Legalität, Legitimität [Legality and Legitimacy], in 5 HISTORISCHES WÖRTERBUCH DER PHILOSOPHIE [HISTORICAL DICTIONARY OF PHILOSOPHY] 163 (Joachim Ritter \& Karlfried Gründer eds., 1980); Würtenberger, supra note 1 , at $734-40$.

19. See Weber's pure types of legitimate government: rational, traditional, charismatic legitimation. Max Weber, Grundriss der Sozialökonomik [Basic Concepts of Social Economics], in III ABTEILUNG: WIRTSCHAFT UND GESELLSCHAFT [ECONOMY AND SOCIETY], 19 (2nd ed., 1947); see also PETERS, supra note 3, at 514 .

20. See PETERS, supra note 3, at 524-79 (for a fuller analysis of ex ante and ex post legitimation).

21. See id. at 515-24 (for a full account and explication of this ethically founded concept of legitimacy). 
In addition to these quite thoroughly developed conceptualizations of the legitimacy of governments, we find several elements and criteria that are held to contribute to the legitimacy of the exercise of public authority. As mentioned earlier, such criteria are transparency and efficiency of government (or more broadly, public authority), and actions and accountability of governments/public authorities. While transparency and accountability are clearly democracy-related, efficiency is not necessarily so. Finally, we may add expertise as a factor that can contribute to the acceptability of acts of public authorities. In passing, it may be mentioned that, particularly in Germany, efficiency has a negative ring, both for historical reasons (the alleged "efficiency" of the Third Reich) and due to an aversion to "technocracy" (viz. the EU/EC). However, anyone who closely follows the sentiments of citizens must be aware that the lack of efficiency on the part of public authorities is a major source of discontent ${ }^{22}$-open in democratic systems and clandestine in closed societies.

\section{TRANSNational Democracy and ALternative STRategies of LEGITIMATION OF THE EXERCISE OF PUBLIC AUTHORITY BEYOND THE STATE}

\section{A. Why Is There a Need for Legitimating Public Authority Beyond the State?}

Before going into details, it is necessary to establish why the question of the legitimacy of exercising public authority beyond the state is relevant, and to what extent. With regard to supranational organizations like the EU/EC, the answer can be short. The EU/EC, as the most advanced supranational institution, exercises public authority that is established by international treaties that, in turn, constitute the constitutional structure establishing legislative, executive, and judicial functions. The EU/EC acts through these organs, in many instances with immediate binding effects on the member states and $\mathrm{EU}$ citizens - the latter effects even entailing restrictions on the enjoyment of fundamental rights. There can be no question that the EU/EC exercises public authority within an institutional structure and legal order that is distinct from the legal orders of the member states, and therefore that it needs justification in

22. See id. at 500-05 (on the crisis in acceptance of the EU/EC). 
order to be accepted as legitimate. ${ }^{23}$ Hence the intensive debate over the need for the democratization of the EU/EC that, in fact, has made some progress over the years.

The case is less evident with regard to the actions of international intergovernmental and non-governmental organizations (IGOs, NGOs). At first glance, it seems doubtful whether such organizations wield public authority in any meaningful sense at all. Neither type of organization has immediate jurisdiction over individuals, be they natural or juridical persons. In addition, according to realists and neo-realists-as they untiringly emphasizeinternational governmental organizations are but instruments in the hands of the member states, particularly the great powers. ${ }^{24}$ Therefore, there appears to be no place for legitimation considerations. However, this is legally and factually false. Even accepting that in highly politicized IGOs like the United Nations power politics play an important role (much to the detriment of the authority of the UN), ${ }^{25}$ many other important IGOs, though not free of political power plays in the national interest, pursue their public tasks based on their functions and powers quite effectively. Especially where their bureaucracy is well equipped with expert staff-as is the case with the ILO, WHO, IMF and WTO or ICAO-many IGOs' policy and decisionmaking is effective and has a considerable impact not only on the member states and their internal legal order, but also to a large extent, albeit indirectly, on the people. Thus, domestic labor law, health law, trade law, and air transport law are heavily influenced and even shaped by the lawmaking of these IGOs. ${ }^{26}$ In addition, one has to realize that, in many instances, domestic law that appears to be genuinely "homemade" is actually nothing but a rubberstamped regulation worked out at the level of IGOs by teams of international and national administrators (civil service). ${ }^{27}$ This is particularly true in the case of so-called framework

23. Id.

24. See discussion supra note 4 .

25. Thus, during the Cold War major conflicts between the great powers were mainly discussed-and sometimes resolved-at summit meetings outside the framework of the United Nations. It was not until the end of the Cold War that the United Nations, in particular the Security Council, gained political weight and could begin to act as originally envisaged by the UN Charter. For a short assessment of the UN Security Council's reduced role during the Cold War, see Jochen A. Frowein, United Nations, in IV ENCYCLOPEDLA OF PUBLIC INTERNATIONAL LAW [hereinafter EPIL] 1029, 1032 (Rudolf Bernhardt et al. eds., 2000).

26. See STEPHAN HOBE, DER OFFENE VERFASSUNGSSTAAT ZWISCHEN SOUVERÄNITÄT UND INTERDEPENDENZ [THE OPEN CONSTITUTIONAL STATE BETWEEN SOVEREIGNTY AND INTERDEPENDENCE] 248-93 (1998) (on the impact of the actions taken by such IGOs on domestic legal orders and the role of the member states).

27. See CHRISTIAN TIETJE, INTERNATIONALISIERTES VERWALTUNGSHANDELN 288-487 (2001). 
conventions that are continuously amended according to the standards of expert knowledge, as either Protocols to conventions, or as recommendations that in turn are often implemented on the domestic level, through executive orders or other regulatory means, below the level of parliamentary legislation, thereby bypassing the national legislative process. ${ }^{28}$ Remembering that, in this process, environmental NGOs in particular play an increasingly important role, democratic legitimation proper of this kind of lawmaking is scant. In sum, there is clearly a need to think about the legitimacy of the inter-, supra-, and transnational exercise of public authority. ${ }^{29}$

\section{B. Can Traditional State-Centered Concepts of Legitimacy be Transferred to Levels Beyond the State?}

Another point to be addressed before going into detail is whether the mostly but not exclusively state-centered legitimation concepts or strategies can be transferred to levels beyond the state. At this juncture, we may leave aside the case of the EU/EC, which is a much more state-like entity than any other inter- or transnational institution-although even here, as mentioned earlier, there are serious objections to the possibility of democratizing the EU/EC. And it has to be admitted that the democratization of the EU/EC, as far as it has been achieved, is still quite different from that of democratic states. To name but one example, the EC Parliament is not elected in a genuine general election. Rather, the elections are held, according to domestic electoral law and in domestic precincts of very divergent size, in the various member states, which leads to enormous differences in the weight of the individual vote. Also, there are no European-wide political parties competing, but merely candidates of the national parties. Thus, the outcome of the "domestic" European elections is determined by domestic political issues more than by any genuinely European ones. But the real problems arise with democratization on the inter- and/or transnational level. Universal suffrage is out of the question for two reasons: first, the political and socio-cultural conditions around the world are so vastly different that organization and realization of universal elections may be a vision, but not one realizable in the foreseeable future. Secondly, we are facing

28. See id. at 247-50, 391-92.

29. See COMMISSION ON Global GOVERNANCE, OUR GlOBal NEIGHBOURHOOD 66 (1995) ("The need for greater democracy arises out of the close linkage between legitimacy and effectiveness.... [A]s the role of international institutions in global governance grows, the need to ensure that they are democratic also increases.") 
a multitude of international public authorities, each needing legitimation, but to a different degree according to their very different important tasks and functions. Universal suffrage could not possibly cover all of these different needs, unless a World Government is installed in their place-a vision that is equally unrealistic and undesirable, as Kant warned more than two hundred years ago. ${ }^{30}$ Of course, one may choose a more modest approach by selecting certain important organizations for sectoral democratization. As early as the late 1920s, Walther Schücking proposed a second chamber for the League of Nations that would be elected within the member states-a proposal that was repeated in a modified form in our time by the Commission on Global Governance in $1995{ }^{31}$

The upshot of these remarks is that there seems to be consensus that a direct transfer of the concept of legitimation by democracy to the international level is not feasible in the foreseeable future. Whether analogous forms of legitimation can be applied, what kinds of surrogates for pure democratization are available, and what other measures to foster legitimacy of public authorities beyond the state could be implemented will now be discussed.

\section{Models for Transnational Democracy}

In his excellent piece "Democracy Beyond Borders? Globalization and the Reconstruction of Democratic Theory and Politics, ${ }^{32}$ Anthony McGrew categorizes approaches to the problem of transnational democracy under three major headings: "liberal-democratic internationalism" or "neighbourhood democracy;" "radical communitarianism: demarchy;" and "cosmopolitan democracy." 33 The main features of the liberal-democratic position are a rejection of World Government or World Federalism and an understanding of "global governance as a set of pluralistic arrangements by which states, international organizations, international regimes, non-governmental organizations, citizen movements and markets combine to regulate or govern aspects of global affairs. ${ }^{134}$ As McGrew observes:

30. See Immanuel Kant, Kant's Perpetual Peace: A Philosophical Proposal 29, 40-41 (Helen O'Brien trans., 1927).

31. See COMMISSION ON Global GoverNaNCE, supra note 29; Anthony McGrew, Democracy Beyond Borders?, in THE Global TRANSFORMATIONS READER: AN INTRODUCTION TO THE Globalization DEBATE 405, 408 (David Held \& Anthony McGrew eds., 2000).

32. McGrew, supra note 31.

33. Id. at $408,410,413$.

34. Id. at 408 . 
Central to [the Commission's] proposals is a reformed United Nations system buttressed by the strengthening, or creation, of regional forms of international governance, such as the EU. Through the establishment of a peoples' assembly and a Forum of [Global] Civil Society, both associated with the UN General Assembly, the world's peoples are to be represented directly and indirectly in the institutions of global governance. $^{35}$

In other words, the liberal-democratic position advocates some form of democratically elected representation of the peoples, possibly through national parliaments, rather than visionary universal suffrage. This proposal carries considerable weight, particularly because it finds support in the similar models of peoples representation on the regional level as, for instance, provided within the EU/EC in the form of the Council of Regions, where representatives of local governments have been given some kind of consultative status (with more or less success). ${ }^{36}$

The main feature of the "radical communitarianism" or "demarchy"- as a "bottom-up" approach-is "the active participation of people in decision making, sometimes as representatives of specific interests they themselves have, but often too as the trustees of interests that cannot speak for themselves. ${ }^{, 37}$ In a sense, this approach appears not to differ very much from the liberaldemocratic position. But, in stark contrast to the latter, such participation by the people or their representatives in decisionmaking is not envisaged as taking place within the existing international institutions. Instead, "democracy and democratic legitimacy are not to be sought in geographically-bounded entities like nation-states, but rather in functional authorities of varying geographical scope run by individuals selected by lot from among those with a material interest in the issue in question." ${ }^{38}$ As McGrew rightly observes, the

35. Id.

36. On the Committee of Regions (Ausschuß der Regionen), see TREATY ESTABLISHING THE EUROPEAN COMMUNITY, March 25, 1957, arts. 263-65, O.J. (C 340) 3 (1997) (as amended by the Treaty of Amsterdam Amending the Treaty on European Union, the Treaties Establishing the European Communities and Certain Related Acts, Oct. 2, 1997, O.J. (C 340) 1 (1997)), available at $\mathrm{http} / / /$ europa.eu.int/eur-lex/en/treaties/dat/ ec_cons_treaty_en.pdf; THOMAS OPPERMANN, EUROPARECHT [EUROPEAN LAW] 406-09 (2nd ed. 1999); RUDOLF STREINZ, EUROPARECHT [EUROPEAN LAW] 340-42 (4th ed. 1999).

37. See McGrew, supra note 31, at 411 (citing J. Burnheim, Power-Trading and the Environment, 4 ENVTL. POL. 49 (1995)).

38. See McGrew, supra note 31, at 411 (citing J.S. Dryzek, Political and Ecological Communication, 4 ENVTL. POL. 13 (1995)). 
"demarchy" approach is basically "subversive of existing forms of global governance since its objective "is to chip away and ultimately destroy sovereignty at all levels of social life, ${ }^{, 39}$ while the liberal-democratic approach is reformist.

The "cosmopolitan democracy" approach is reformist as well, but it is founded on a "philosophy" that differs from that of the liberal-democratic position in that it rejects unbounded liberal individualism. As McGrew observes, the model is underpinned by an ethic of democratic autonomy which differs from "the self-interest of liberal individualism[,] since it refers to 'a structural principle of self-determination where the "self" is part of the collectivity or "majority" enabled ... by the rules and procedures of democratic life. . . . Hence, this form of autonomy can be referred to as "democratic autonomy"-an entitlement...within the constraints of community." "40 McGrew continues, again citing Held, "[t]o achieve this, under contemporary conditions, requires the embedding of democratic practices more deeply 'within communities and civil associations by elaborating and reinforcing democracy from "outside" through a network of regional and international agencies and assemblies that cut across spatially delimited locales." ${ }^{, 41}$ From a legal point of view, it is of special interest that Held recognizes "the necessity for a cosmopolitan democratic law, that is, law which transcends the particular claims of nations and states and extends to all in the 'universal community." "42 This fully conforms with the Weltinnenrecht's concept of a World Law ${ }^{43}$ that is constituted by traditional international law but is at least partially transformed into a law that extends to state and non-state-actors and thus forms the underpinning of the global community, or, in other words, coordinates and constitutionalizes the pluralism of transnational public authorities. ${ }^{44}$

It appears that the "cosmopolitan" approach is not only quite in line with the ongoing process of the partial transformation of international law and its constitutionalization, but also allows for a reformist and/or gradualist implementation of the model. The only critical point is that the "anti-

39. See McGrew, supra note 31, at 412 (quoting J. Burnheim, Power-Trading and the Environment, supra note 37 , at 64).

40. See McGrew, supra note 31 , at 413 (citing DAVID HELD, DEMOCRACY AND THE Global ORDER: FROM THE MODERN STATE TO COSMOPOLITAN GOVERNANCE 156 (1995)).

41. See McGrew, supra note 31, at 413-14 (citing HELD, supra note 40, at 237).

42. HELD, supra note 40, at 228.

43. See Jost Delbrück, Prospects for a "World (Internal) Law?": Legal Developments in a Changing International System, 9 IND. J. OF GLOBAL LEGAL STUD. 401 (2002).

44. See id. 
individualist" aspect is acceptable only if it is not meant as a rejection of the indispensable protection of the individual's fundamental rights and freedoms in favor of self-determination of the collectivity. However, it appears that what is meant by the "anti-individualist" character of the cosmopolitan model is the recognition that individual fundamental rights and freedoms are not absolute. Rather their exercise is subject to ethical and constitutional restraints; that is, they have to be used in a socially responsible manner, a position that is clearly evidenced in the jurisprudence of, for instance, the German Constitutional Court. ${ }^{45}$ With this proviso, the "cosmopolitan" model is commensurate with the vision of a globalization with a human face. However, it must be admitted that, realistically, we are at the beginning of building a global society under law. The necessary degree of legitimation of transnational public authorities by democratic or analogous processes is not at the doorstep. Therefore, alternative means of legitimation, including surrogates for "real" democracy, are becoming extremely relevant. For in the transitional period, until more transnational democracy becomes a reality, public trust in the institutions of global governance might decline to a degree that would render major reforms politically impossible.

\section{Surrogates for Democratization and Other Alternative Means of Legitimation on the Transnational Level}

As mentioned earlier, participatory surrogates for democratic legitimation and other means of legitimation such as efficiency, transparency, accountability, ex post acceptance of public acts characterized by expertise, and rationality ${ }^{46}$ are discussed in this context. ${ }^{47}$ Out of the number of surrogates (delegation of

45. See BVerfGE 32, 98, at 107 (the decision of the German Federal Constitutional Court (Bundesverfassungsgericht)). Interpreting art. 4(I) of the Basic Law, guaranteeing the freedom of religion, the Court first observed that "freedom of belief is not unlimited" and then continued, "The freedom guaranteed by Art. 4 (I) of the Basic Law, like all the fundamental rights, has as its point of departure the view of man in the Constitution, i.e., man as a responsible personality, developing freely within the social community. These community ties of the individual recognized by the Constitution impose formal limits on even those fundamental rights which are guaranteed unreservedly." DONALD P. KOMMERS, THE CONSTITUTIONAL JURISPRUDENCE OF THE FEDERAL REPUBLIC OF GERMANY 453 (1989) (emphasis added).

46. See PETERS, supra note 3, at 517-24 (for a thorough discussion of ex ante and ex post legitimation of public authority or their constitutional basis).

47. It is a matter of definition whether the criteria of transparency and accountability are essential elements of democracy or can also stand in their own right. If one accepts the first view then legitimation through transparency, accountability and ex post acceptance constitute a process of partial democratization. In the end, it does not really matter which position is preferred as long as the result of the compliance with these criteria is increased legitimacy of the public authority exercised beyond the State. 
members of national parliaments, participation of representatives of groups particularly interested in specific subject matters dealt with on the intenational level, and participation of NGOs), only one-the role and function of NGOs as legitimating factors-will be taken up at this point. NGOs, widely held not to be subjects of international law, and yet recognized as such in specific contexts contrary to the traditionalists' view, ${ }^{48}$ are playing an ever more important role in global governance. They are accorded a consultative status in various international organizations, or subunits thereof, that permits them to participate in the deliberations of such organizations. Additionally, NGOs are vested with the right to enforce human rights by conceding to them locus standi before international human rights courts and other monitoring bodies. They also participate in international lawmaking processes, either as consultants or as initiators of important international conventions (e.g. the Convention on the prohibition of anti-personnel landmines). ${ }^{49}$ Furthermore, they play an important role in monitoring compliance with international conventions promulgated in the international public interest. Last but not least, NGOs substantially contribute to a pluralistic international public discourse, with the NGOs envisaging themselves as advocates of the international public interest. It is particularly this latter point that is viewed critically in many quarters, because NGOs do not possess a democratic mandate and in many cases are not internally democratically structured. Although NGOs offer a unique opportunity for private individuals to participate in international political discourse, their lack of democratic legitimacy leads to criticism. Theoretically, this argument carries weight. However, as we are talking about "surrogates" for pure democratic participation, from a pragmatic point of view, this argument is not convincing. As the saying goes: it is better to have a sparrow in your hands than a dove on the roof. There is ample evidence that a number of NGOs have played a constructive and effective role in various settings

48. See VOLKERRECHT § 6, marginal no. 20 (Knut Ipsen ed., 1999). A more differentiated positon is taken by Karl Doehring, who rejects the notion that NGOs generally possess international legal personality but concedes that states could accord such a (limited) status to NGOs as they did in the case of the International Committee of the Red Cross (ICRC). VOLLKERRRECHT, supra, marginal nos. 196-201. For the many other instances, in which NGOs have been accorded limited derivative international legal personality, see generally MICHAEL HEMPEL, DIE VOLKERRECHTSSUBJEKTIVITÄT INTERNATIONALER NICHTSTAATLICHER ORGANISATIONEN [THE INTERNATIONAL LEGAL PERSONALITY OF INTERNATIONAL NON-GOVERNMENTAL ORGANIZATIONS] (1999).

49. See LORI F. DAMROSCH ET. AL., BASIC DOCUMENTS SUPPLEMENT TO INTERNATIONAL LAW-CASES AND MATERIALS 513-22 (4th ed., 2001) (citing Convention on the Prohibition of the Use, Stockpiling, Production and Transfer of Anti-Personnel Mines and on Their Destruction, Sep. 18, 1997, 36 I.L.M. 1507 (entered into force Sep. 18, 1997)); OTTO KIMMINICH \& STEPHAN HOBE, VOLLKERRECHT 467 (7th ed., 2000). 
(compliance control, human rights monitoring, and implementation of environmental law) that outweighs their internal democratic deficit. ${ }^{50}$ Furthermore, providing a stringent legal framework-as already exists in some instances-that NGOs would have to abide by in order to be admitted as participants in the international system could enhance their legitimacy. ${ }^{51}$

Efficiency has a legitimizing effect. As an example of the negative effects of a lack of efficiency, one can point to the fate of UNESCO. When the chaotic mismanagement in the secretariat, the waste of money, and corruption became public, not only UNESCO itself, but international organizations in general, suffered a major loss of reputation. ${ }^{52}$ The decline of acceptance of the EU/EC within the member state nations is also widely held to be due to the lack of efficiency (similar effects can be observed within states, as well). ${ }^{53}$

Although transparency and accountability are closely related to the democratic model, they are also valid as independent criteria of legitimacy. This is certainly true with regard to the market, but it is also true for public authorities. Governmental transactions behind closed doors are likely to cause distrust. Of course, to some degree, there are limits to the request for transparency, such as when rights of individual citizens to the protection of their privacy are at stake, but this scenario is the exception rather than the rule. And it is even less relevant on the level beyond the state. At the same time, there are many ways by which transnational or international authorities can promote transparency of their decisionmaking: for instance, through regular, meaningful, understandable, and accessible reports about their plans and activities. Furthermore, international institutions can hold more open meetings and thereby allow for better informed media reporting, to name but a few of the possibilities. The same applies to accountability. Of course, one may ask "accountable vis-à-vis whom?" Here it appears to be no coincidence that transparency and accountability are usually named together. Transparency

50. See Daniel Thürer, The Emergence of Non-Governmental Organizations and Transnational Enterprises in International Law and the Changing Role of the State, in NON-STATE ACTORS AS NEW SUBJECTS OF INTERNATIONAL LAW: FROM THE TRADITIONAL STATE ORDER TOWARDS THE LAW OF THE GLOBAL COMMUNITY $37-58$ (1999) (proceedings of an International Symposium of the Kiel WaltherSchücking-Institute of International Law, March 25-28, 1998).

51. The argument that subjecting NGOs to legal rules would deprive them of their independence and impair their critical function is beside the point: independence does not mean a right to act within a "law free zone."

52. See Roland Bank, United Nations Educational, Scientific and Cultural Organization, in IV EPIL, supra note 25 , at $1093,1097-98$.

53. See PETERS, supra note 3, at 500-05 (for further references). 
entails accountability, in that public authorities beyond the state making their transactions public can then be held accountable by the various global non-state actors, including the media, forcing the public authorities to react constructively to public critique. WTO and IMF are examples in point, as they are revising their decisionmaking processes to provide greater transparency. ${ }^{54}$

Finally, legitimation by expertise and rationality of actions are important means to promote public acceptance of institutions of global governance. Convincing the public that the actions of inter-, supra-, and transnational public authorities are based on sound expertise and rational grounds can greatly enhance ex-post legitimation. It has to be noted that specialized NGOs, through their expert inputs, can play an important role in this respect as well.

\section{CONCLUSION}

The historic record shows that we have moved from the legitimation of public authority based on one generally accepted concept-legitimacy by metaphysical myths or the will of God-to a variety of legitimation concepts and strategies. This diversification of legitimacy concepts clearly reflects the increasing refinement and sophistication of governmental structures as well as the growing social pluralism in the modernizing individual societies. The preceding analysis has also shown that in modern state theory and practice no catch-all concept of legitimacy is prevalent. Although an increasing number of states adhere to democracy as the basis of legitimate government, other criteria of legitimacy are also applied, partly concurrently, partly in competition with one another.

It appears to be justified to postulate that, in view of the pluralism of public authorities beyond the state, the pursuance of different concepts and strategies of legitimation is an adequate response to the challenge of legitimizing global public authority. From a theoretical point of view, this may be problematic, but from a pragmatic point of view, an "all-or-nothing" approach appears to be neither politically feasible nor in the interest of the gradual and effective formation of legitimate global governance. The ultimate goal remains: a rule of law-based and at least partially democratized global order of peace and justice.

\footnotetext{
54. See Daniel C. Esty, Non-Governmental Organizations at the World Trade Organization: Cooperation, Competition, or Exclusion, 1 J. INT'L ECON. L. 123 (1998); Ibrahim F.I. Shihata, The World Bank and NonGovernmental Organizations, 25 CORNELL INT'L L.J. 623, 640 (1992).
} 
